DOI: 10.20472/IAC.2019.052.046

LERATO MOTHIBI

North West University, South Africa

\title{
THE IMPACT OF FOREIGN DEBT AND GOVERNMENT DEBT ON ECONOMIC GROWTH IN SOUTH AFRICA
}

\begin{abstract}
:
Debt management has always been a major concern for many developing countries. South Africa's foreign debt was reported to have reached its highest in 2017, where debt levels reached 48.8 percent of gross domestic product. At economically sustainable levels, borrowing in itself ought not to be an issue, however it is rather unfortunate that most sub-Saharan nations including South Africa have accumulated high, unsustainable amounts of debt, which may have constrained the progression of economic growth and development. Making use of the auto regressive distributive lag model (ARDL), this study examines the relationship between foreign debt and government debt on economic growth in South Africa from 1980 to 2018. The findings of the study reveal that sound debt management may lead to economic prosperity.
\end{abstract}

\section{Keywords:}

South Africa

Government debt

Foreign debt

Economic growth

JEL Classification: A10, C01, B26 


\section{INTRODUCTION}

Debt remains one of the most significant challenges faced by many countries around the world. South Africa, and many other countries such as Japan, Greece, Lebanon, Italy and Portugal are amongst those distinguished by Brinded (2016) to be amongst the top countries around the globe with the most noteworthy external debt-to GDP ratio. The fundamental cause of the increasing debt levels was fuelled by the 2007/2008 global financial and economic crisis (Holtfrerich et al., 2016). The continuous rise of debt, as well as its excessive negative effects has drawn the attention of economists and policymakers. Easterly (2002) asserts that 41 countries around the world have been identified by the World Bank as heavily indebted poor countries (HIPCs). However, even though some of these countries qualified to receive debt relief over the previous two decades, factors that lead to increased amounts of debt are not always easily resolved by debt relief, and some of these factors could last for a prolonged period (Easterly, 2002). In the global community, Mutasa (2003) and Audu (2004) show that in many developing countries, a significantly enlarged amount of debt is an obstacle to the nation's financial improvement. This is additionally attested to by Reinhart and Rogoff (2010), who demonstrate that in the event that the debt-to-GDP ratio surpasses 90 percent, at that point economic growth will start to decline.

Many developing countries such as South Africa face trade debt arrears and increased financing cost due the extensive amounts of debt accumulated. Additionally, one problem associated with the accumulation of debt service payments is related to the fact that debt is financed for more than it was initially obtained, which therefore hinders the advancement and development process of a nation (Gohar \& Bhutto, 2012). The growing consequences of debt prove to be a vital concern for the South African economy, as, in 2017, South Africa's foreign debt was reported to have reached its highest since the 1980s, as foreign debt accounted for 48.8 percent of gross domestic product (GDP) (Budget Review, 2018). The increasing debt levels also play a vital role in the deterioration of the economy. As revealed by Statistics South Africa (StatsSA) (2018), the South African economy shrunk by $0.7 \%$ in the second quarter of 2018 , following a decrease of $2.6 \%$ in the first quarter of 2018. Furthermore, South Africa has low saving investments rates, and therefore the need to borrow from other developed countries. Like many other countries, SA wishes to improve the living conditions of its inhabitants in such a way that promotes investments, as well as economic growth. Since the country suffers from continuous budget deficits, high unemployment levels, poverty, political instability and frail economic growth, this therefore prompts the need to borrow.

Given the remarkable increase of debt accumulation in SA, there is limited empirical analysis conducted, as many studies focus mostly on the effects of either external debt, or public debt on economic growth in African countries such as the investigation of Sulaiman and Azeez (2012) and Moki (2012), and not explicitly on the effect of both foreign and domestic debt on economic growth of South Africa. Meanwhile, existing evidence by other researchers provides conflicting results, as some evidence reveals that debt accumulation is not necessarily detrimental to an economy, but rather could be beneficial and have a positive relationship to growth (Muhdi \& Sasaki, 2009), while some evidence reveals that debt will negatively affect the growth of a nation (Geiger, 1990). The conflicting results obtained by researchers leads to the need for further 
research on the impact of both foreign and domestic debt on economic growth in South Africa. In order to tackle the debt issue in South Africa, this study's main objective is to analyse the impact of foreign debt and government debt on economic growth in South Africa.

\subsection{LITERATURE REVIEW}

\subsubsection{Theoretical framework on government debt}

Government debt, also known as public debt, refers to money that is owed by the central government to residents or even creditors within the borders of the country or domestically. As a means of supporting public and profitable investment such as investment in human resource, physical infrastructure and spending on healthcare and education, government may accumulate public debt (Belguith \& Omrane, 2017). Accordingly, political factors, and institutional and structural factors are identified in the existing literature as some of the factors that affect public debt. Furthermore, Drazen (2000), Imbeau and Pétry (2004), Swaray (2005), cited by Belguith and Omrane (2017) have identified economic growth, budget deficit, inflation, monetary policy and openness, and public spending as economic factors that affect the trajectory of public debt. Belguith and Omrane (2017) likewise further also indicate that the size of public debt can also be affected by political instability and polarisation.

An investigation by Varughese (1999) states the overwhelming viewpoints of the classical economists concerning public debt as the following: Firstly, the credit account of the government diverts resources from gainful private business. Furthermore, when the government keeps borrowing more money, this prompts unpredictable future financing in a manner that expands the budget. An expanded budget will then also have to go for budget revisions, of which this leads to further costs that have to be paid in terms of funding the interest payments of the debt. Furthermore, the third point declares that spending deficiencies are less torturous than current taxes. In conclusion, large amounts of debt lead to currency devaluation. This last point alludes to the fact that since there is a cost attached to borrowing money, Kwoba and Kosimbei (2005) declare that borrowed money will be paid for twice; that is, once in gathering the premium charges and again in satisfying the real sum obtained. On the other hand, monetarists have called attention to the fact that financed debt leads to crowding-out private investment, which further leads to an increase in interest rates. This, therefore, indicates that government debt will have a negative impact on a country's growth. Furthermore, the debt overhang theory postulates that, in an event when the debt surpasses the government's repayment ability, future debt service costs will lead to discouraged investments, be it domestically or internationally, which will therefore also affect economic growth.

\subsubsection{Theoretical framework on foreign debt}

External debt/foreign debt is referred to as the total public and private debt that is owed to nonresidents of a country and is repayable in foreign currency (Ahmed et al., 2015). Two main opposing schools of thought are identified by Diallo (2009) on the economic theory of external debt, namely the Keynesian and the neoclassical schools of thought. As a result of the investment that debt generates, according to the Keynesian school of thought, the level of indebtedness does not lead to changes for either the current or future generations. On the other hand, the classical economists regard indebtedness as a potential future tax for the government. 
Neoclassical economists identify external debt as one of the most important sources of capital for a nation, and therefore indicate a positive impact of external debt on economic growth and investment. However, other economists contradict this view and believe that external debt is in fact one of the factors that hampers an economy and identify debt sustainability, debt accumulation, inability to meet debt obligations, and the inability to raise foreign loan in its respective currency as potential problems related to external debt (Diallo, 2009). Many economists have studied the impact of external borrowing on economic growth. The findings of researchers are contradictory, as some researchers found that there exists a positive relationship between external debt and economic growth, while other researchers found that foreign debt has a negative impact on economic growth as a result of the sufficient distribution of resources, and furthermore, that foreign debt could, if used effectively and efficiently, add value to a nation's economic growth (Diallo, 2009).

\subsubsection{Empirical literature review}

Making use of different econometric models and statistical tools, a number of studies have attempted to investigate the relationship between foreign debt and economic growth in both developing and developed countries. However, the results of these studies are contradictory in their conclusions regarding the impact of external debt of economic growth as well as the impact of government debt on economic growth.

For example, the investigation of Hassan and Mamman (2013) recommends that borrowing of external debt ought to be diverted towards the real sectors of an economy so as to produce a noticeable effect on the nation. Their study uncovers that external debt has a positive association with economic growth in Nigeria. Malik, Hayat and Hayat (2010) made use of time series economic analysis and investigated the impact of external debt on economic growth in Pakistan utilising data from 1972 to 2008. The outcome of their study showed a negative and significant relationship between external debt and growth in Pakistan. The examination of the results indicated an extension if external debt levels will bring about a decrease in economic growth. Furthermore, Kwoba and Kosimbei (2015) contend that debt service costs additionally add to the elevated foreign debt levels, since this would imply that a country will be paying twice as much as the amount initially borrowed as a result of service costs.

Focusing on the impact of external debt together with debt servicing costs in Nigeria, the investigation of Ayadi and Ayadi (2008) used time series data from 1970 to 2007, where their results revealed that debt and its service costs contrarily influence economic growth. Exploring the role of external debt on economic growth in Mauritania, Mahmoud (2015) observes a negative relationship between economic growth and debt servicing. Furthermore, utilising the Keynesian framework, Leao (2013) in his study affirmed that, under full employment, a reduction in the public debt ratio might be prompted by an increase in expenditure. Moreover, making use of annual data from 1976 to 2001, Mah et al. (2015) examined the effect of government expenditure on government debt in Greece. Their results reveal that there exists a positive and noteworthy relationship between government consumption and expenditure. Furthermore, Cooray et al. (2016) further reveal that the accumulation of higher public debt is a result of the increased corruption in a nation. Da Veiga et al. (2014) confirm that debt levels are influenced by the structure of revenue and expenditure of a country. They further also confirm that higher debt 
levels are also associated with higher unemployment rates. Utilising a panel regression, Sinha (2011) attests that the size of sovereign debt is impacted by loan fees, the level of FDI, economic growth, inflation and the current account balance.

A study by Reinhart and Rogoff (2010) evaluated the development of public debt and the growth rate for a panel of 40 nations over the last two centuries. The examination of their information uncovers a weak relationship between government debt and growth for government debt levels below the limit of 90 percent of GDP. Furthermore, making use of 61 countries, Chiu and Lee (2017) investigated the impact of public debt on economic growth, where their results revealed that a nation's growth is negatively affected by rising debt levels under a high-risk environment. Furthermore, the results also revealed that under a low political and financial risk environment, there exists a weak effect of public debt on economic growth; while under a reduced composite and economic risk environment, in order to stimulate economic growth, an increase in public debt would be helpful. Similarly, making use of a panel Granger causality method, the results of Dumitrescu (2014) and Swamy (2015) conclude that a negative effect on debt is caused by foreign direct investment, population growth, government expenditure, real GDP growth, investment and inflation; and a positive impact is brought about by final consumption expenditure, gross fixed capital formation and trade openness. In addition, many studies have investigated the debt problem, taking into account only government debt or foreign debt, especially in developing countries. This study therefore aims to contribute to the literature by analysing the impact of both government and foreign debt on economic growth in South Africa.

\subsection{METHODOLOGY}

\subsubsection{Data and sample period}

Based on the aforementioned, this study follows a quantitative research approach using annual data obtained from the South African Reserve Bank from 1980 to 2018. This time period was chosen primarily based on the availability of data. The variables utilised in this study include real gross domestic product per capita (GDP), total loan debt of national government (GD), total foreign debt of national government (FD), national government expenditure (EXP), and gross fixed capital formation: total investments (INV).

\subsubsection{Model specification}

The study adapts the autoregressive distributed lag model (ADRL) developed by Pesaran et al. (2001) to analyse both the long- and short-run effects between government debt and foreign debt on economic growth in South Africa. The use of this model lies behind the fact that among other cointegration techniques, the advantage of using the ARDL method is based on the fact that it allows for variables to be integrated at either $\mathrm{I}(0)$ or $\mathrm{I}(1)$ or jointly at $\mathrm{I}(0)$ and $\mathrm{I}(1)$ order of integration (Habanabakize et al., 2017). The model will, however, be invalid if any variables are integrated at order I(2). The first step in the analysis requires the use of the augmented Dickey Fuller (ADF) unit root test to ensure that variables are not integrated at order I(2). The following $A D R L$ model below is estimated for the empirical analysis:

$$
\Delta L G D P_{t}=\beta_{0}+\sum_{i=1}^{k} \beta_{1 i} \Delta L G D P_{t-i}+\sum_{i=1}^{k} \beta_{2} \Delta L G D_{t-i}+\sum_{i=1}^{k} \Delta L F D_{t-i}+\sum_{i=1}^{k} \beta_{4 i} \Delta L E X P_{t-i}+\sum_{i=1}^{k} \beta_{5} \Delta L I N V+
$$


$\alpha_{1} L G D P_{t-1}+\alpha_{2} L G D_{t-1}+\alpha_{3} L F D_{t-1}+\alpha_{4} L E X P_{t-1}+\alpha_{5} L I N V_{t-1}+\varepsilon_{t}$

Where $\triangle L G D P$ denotes the natural logarithm of real gross domestic product per capita at a time $\mathrm{t}$, followed by $\triangle L G D$, which denotes the natural logarithm of government debt at a time $\mathrm{t}$, followed by $\triangle L F D$ denoting the natural logarithm of foreign debt at a time $\mathrm{t}$, which is then followed by $\triangle L E X P$ denoting the natural logarithm of gross national expenditure at a time $t$, which is lastly followed by $\triangle L I N V$ denoting the natural logarithm of investment at a time t. Furthermore, the intercept and the error term are denoted by $\beta_{0}$ and $\varepsilon_{t}$ respectively. The number of lags is indicated by $k$, followed by the short-run dynamics, which are indicated by $\beta_{1}-\beta_{5}$ followed by the long-run dynamics, which are indicated by $\alpha_{1}-\alpha_{5}$.

Based on equation 1 above, the study makes use of the Pesaran et al (2001) approach for bounds testing in order to test the hypothesis for co-integration:

(No cointegration-null hypothesis): $\alpha_{1}=\alpha_{2}=\alpha_{3}=\alpha_{4}=\alpha_{5}=0$

(Cointegration-alternative hypothesis): $\alpha_{1} \neq \alpha_{2} \neq \alpha_{3} \neq \alpha_{4} \neq \alpha_{5} \neq 0$

To test the above-mentioned hypothesis, the Wald F-test, also known as the bounds test, is used, where the estimates of the F-values are compared with the critical values obtained from the Peseran et al. (2001) table. This is obtained in such a manner where, if the estimated F-value is lower than the critical value obtained from the Peseran et al (2001) table, the null hypothesis will not be rejected, indicating that there is no long-run relationship between the variables. Furthermore, if the F-value is greater than the critical value obtained from the table, this would imply that the null hypothesis is rejected. Indicating that a long-run relationship exists between the variables, this would therefore require the estimation of the error correction model (ECM). Furthermore, if the F-value lies between the upper and lower critical values, this indicates that the results are inconclusive. Derived from equation 1 above, the ECM is established in the following manner:

$$
\begin{aligned}
& \Delta L G D P_{t}=\alpha_{0}+\sum_{i=1}^{k} \beta_{1} \Delta L G D P_{t-i}+\sum_{i=1}^{k} \beta_{2} \Delta L G D_{t-i}+\sum_{i=1}^{k} \Delta L F D_{t-i}+\sum_{i=1}^{k} \Delta L E X P_{t-i}+ \\
& \sum_{i=1}^{k} \Delta L I N V_{t-i}+\phi E C T_{t-1}+\mu_{t}
\end{aligned}
$$

The error correction term and its coefficient are denoted by ECT and $\phi$, respectively, as the coefficient measures the speed of adjustment towards long-run equilibrium. Furthermore, making use of Eviews 9 software, the ARDL model will be estimated, making use of the optimum lag selection based on the Akaike information criterion (AIC). Finally, in order to ensure accuracy of the model, the study will also conduct a number of diagnostics and stability tests, namely stationarity testing, normality tests, autocorrelation, heteroscedasticity and a parameter stability test. 


\subsection{RESULTS AND DISCUSSION}

\subsubsection{Correlation analysis}

As a means of determining the level of association between the variables utilised by the study, a Pearsons correlation test was conducted. As asserted by Evan (1996), the correlation strength is summarised in the following manner: correlation coefficients between (0-0.19) "very weak correlation", between (0.20-0.39) "weak correlation", between (0.40-0.59) "moderate correlation", between (0.60-0.79) "strong correlation" and between (0.80-1.0) "a very strong" correlation is observed. Table 1 below provides a summary the Pearsons correlation test results.

Table 1: Pearson's correlation coefficients

\begin{tabular}{|l|l|l|l|l|l|}
\hline & LGDP & LEXP & LFD & LGD & LINV \\
\hline LGDP & 1.0000 & & & & \\
& --- & & & \\
& --- & & & \\
\hline LEXP & 0.9860 & 1.0000 & & & \\
& {$[28.4219]$} & --- & & & \\
& $0.0000^{*}$ & --- & & & \\
\hline LFD & 0.8923 & 0.9007 & 1.0000 & & \\
& {$[9.4814]$} & {$[9.9479]$} & --- & & \\
& $0.0001^{*}$ & $0.0000^{*}$ & --- & & \\
\hline LGD & 0.8878 & 0.9257 & 0.8777 & 1.0000 & \\
& {$[92526]$} & {$[11.7452]$} & {$[8.7854]$} & --- & \\
& 0.0006 & $0.0000^{*}$ & $0.0000^{*}$ & -- & 1.0000 \\
\hline LINV & 0.9924 & 0.9750 & 0.8978 & 0.8759 & -- \\
& {$[38.9147$} & {$[21.0556]$} & {$[9.7800]$} & {$[8.7071]$} & - \\
& $0.0000^{*}$ & $0.0000^{*}$ & $0.0000^{*}$ & $0.0000^{*}$ & -- \\
\hline Note: * and $^{* *}$ denotes the level of significance at $5 \%$ and $10 \%$ respectively \\
\hline
\end{tabular}

Source: Own table based on results from Eviews 9

The results obtained from the table indicate that at the $5 \%$ level of significance, positive and significant relationships are observed between all the variables utilised by the study. Furthermore, a very strong association is also observed between all the variables utilised. This suggests that there exists a strong association between economic growth, government debt, foreign debt, investment and government expenditure in South Africa.

\subsubsection{ADF unit root testing}

Table 2 below provides a summary of the stationary results obtained by the study.

\section{Table 2: ADF unit root test}

\begin{tabular}{|c|c|c|c|c|c|c|c|}
\hline \multicolumn{3}{|c|}{ Level without trend } & \multicolumn{2}{|c|}{ Level with trend } & \multicolumn{2}{|c|}{$\begin{array}{l}1^{\text {st }} \text { difference without } \\
\text { trend }\end{array}$} & \multirow[t]{2}{*}{$\begin{array}{l}\text { Order of } \\
\text { integration }\end{array}$} \\
\hline & t-statistic & $p$-value & t-statistic & $p$-value & t-statistic & $p$-value & \\
\hline Variable & & & & & & & \\
\hline
\end{tabular}




\begin{tabular}{|l|l|l|l|l|l|l|l|}
\hline LGDP & -0.6633 & -0.8436 & -2.5335 & 0.3016 & -4.1342 & $0.0026^{*}$ & $\mathrm{I}(1)$ \\
\hline LEXP & -0.6415 & 0.8489 & -2.8929 & 0.1769 & -4.4417 & $0.0011^{*}$ & $\mathrm{I}(1)$ \\
\hline LFD & -0.7275 & 0.8273 & -2.2727 & 0.4376 & -4.3306 & $0.0015^{*}$ & $\mathrm{I}(1)$ \\
\hline LGD & -1.3056 & 0.6164 & -2.6668 & 0.2553 & -3.0152 & 0.0429 & $\mathrm{I}(1)$ \\
\hline LINV & -0.4633 & 0.8872 & -3.0550 & 0.1318 & -3.4921 & 0.0138 & $\mathrm{I}(1)$ \\
\hline
\end{tabular}

Source: Own table based on results obtained from Eviews 9

The study made use of the ADF unit root test to ensure that no variables are integrated at order I(2). The results above confirm that no variables are integrated at order I(2), and all variables are stationary at the I(1) level of integration. The results confirm that the ARDL model can therefore be utilised to test for the presence of co-integration.

\subsubsection{Bounds testing}

The study will follow equation 1 in order to determine the best ARDL model based on the information provided by the Akaike information criterion. The lag length selection and model specification were selected making use of an automatic lag length selection in Eview 9 software, where out of the best 20 models, the best model ARDL model was $(1,2,2,2,1)$. Once the best model has been selected, the following step requires the use of the ADRL bound test for cointegration and the results are presented in Table 3 below.

\section{Table 3: Bounds testing for co-integration}

\begin{tabular}{|l|l|l|}
\hline \multicolumn{2}{|c|}{ Value } & \multicolumn{1}{l|}{ K } \\
\hline F-statistic & \multicolumn{2}{|c|}{7.081236} \\
\hline Critical values bounds & Lower bound I(0) & Upper bound I(1) \\
\hline Significance & 2.2 & 3.09 \\
\hline $10 \%$ & 2.56 & 3.49 \\
\hline $5 \%$ & 3.29 & 4.37 \\
\hline $1 \%$ & & \\
\hline Conclusion: Cointegration & & \\
\hline
\end{tabular}

Source: Own table based on results obtained from Eviews 9

The results obtained reveal that the computed F-statistic value (7.081236) is greater than the upper critical values at the $5 \%$ level of significance, indicating that the null hypothesis of no cointegration is rejected, implying that a long run relationship exists between the variables. 


\subsubsection{Long-run analysis}

Because the null hypothesis of no-cointegration was rejected, the results from the long-run relationship are summarised in equation 3 below.

$$
\Delta L G D P=-0.1388 L G D+0.1331 L F D-0.0644 L E X P+0.000 L I N V+11.7999
$$

The results reveal a positive relationship between economic growth and investment. On average, a 1 percent increase in investment will result in a 0.00 increase in economic growth. These results are similar to the results reported by Ncanywa and Makhenyane (2016), who also report a positive relationship between economic growth and investment. Furthermore, a negative relationship between economic growth and government debt was observed. In fact, on average, a 1 percent increase in government debt will result in a 0.13 decline in economic growth. These results are similar to the findings of Kumar and Woo (2010). The results support the idea that instead of government revenue being directed towards infrastructure, healthcare, provision of basic services and education, government revenue and any other additional profit made have to be directed towards paying back debt and debt servicing costs. Furthermore, the literature also contends that political instability can also have an impact on the size of public debt, as some of the borrowed money may be misused by government officials to pursue self-interest above the interest of the people at large, which is the case in South Africa.

The results further demonstrate a negative relationship between government expenditure and economic growth. A 1 percent expansion in government expenditure on average will result in a 0.06 decrease in economic growth. These outcomes are comparable to those detailed by AbuBader and Abu-Qran (2003), who investigated the casual relationship between government expenditure and growth in Egypt, Israel and Syria. The investigation further uncovered a negative long-run relationship in Israel and Syria and a unidirectional negative short-run causality from economic growth to government expenditure. Moreover, Miller and Russek (1997), in their study, inferred that debt financed increments in government expenditure hamper economic growth. The results are in support of the idea that government should be not be making unnecessary and wasteful expenditures. Furthermore, the expenditure pattern in South Africa proves that spending is mostly driven by consumption expenditure, instead of more spending being directed towards investment activities that will in the long run be profitable and beneficial to the country and its people.

Furthermore, economic growth is positively affected by foreign debt. A 1 percent increase in foreign debt will on average result in a 0.13 increase in economic growth. These findings are supported by the study of Mahmoud (2015). The positive relationship is supported by the idea that, in order to help finance budget deficits and to speed up the economy, external debt can be attained and should lead to economic growth (Ahmed et al., 2015). Furthermore, South Africa is faced with a number of economic, political, and social challenges, which, if the administration of the country wants to deal with these problems, need sufficient resources to be made available. In most cases, the government does not have enough capital and has exhausted their domestic credit, which therefore means they would have to borrow money from outside of the country. As the literature postulates, not all borrowing is harmful. The government could be borrowing to actually improve the economic conditions of a country. This is true in the case of South Africa as, even though the country is operating on a fiscal deficit, the country does strive to improve the living conditions of its people by providing services such as free education, healthcare and social services, which are actually identified as the top 3 government expenditures (Budget Review, (2018), and therefore the need to borrow money. Furthermore, the South African government has spent billions of rands to bail out state-owned enterprises. Government bail-outs are essential for 
state0owned entities such as Eskom and the South African Postal Service, as these companies are respectively the sole service provides of energy and postage services in South Africa.

\subsubsection{Short-run and ECM results}

In order to determine the short-run dynamics, the error correction model is estimated and the results are presented in Table 4 below.

Table 4: Short-run and error correction

\begin{tabular}{|c|c|c|c|c|}
\hline Variable & Coefficient & Std. error & t-Statistic & Prob. \\
\hline $\mathrm{D}(\mathrm{LGD})$ & 0.0092 & 0.0403 & 0.2283 & 0.8213 \\
\hline $\mathrm{D}(\mathrm{LGD}(-1))$ & 0.1239 & 0.0449 & 2.7549 & $0.0110^{*}$ \\
\hline $\mathrm{D}(\mathrm{LFD})$ & 0.02131 & 0.0087 & 2.12311 & $0.0233^{*}$ \\
\hline $\mathrm{D}(\operatorname{LFD}(-1))$ & -0.2554 & 0.0087 & -2.9300 & $0.0073^{*}$ \\
\hline $\mathrm{D}($ LEXP) & 0.1003 & 0.0659 & 1.5233 & 0.1407 \\
\hline $\mathrm{D}(\operatorname{LEXP}(1-))$ & -0.1639 & 0.0836 & -1.9593 & 0.0618 \\
\hline $\mathrm{D}($ LINV) & 0.0000 & 0.0000 & 4.7873 & $0.0001^{*}$ \\
\hline CointEq(-1) & -0.2264 & 0.0316 & -7.1651 & $0.0000^{*}$ \\
\hline
\end{tabular}

Source: Own table based on results obtained from Eviews 9

In order to determine the speed of adjustment and the linkages between the long- and short-run relationship of the variables for them to return to equilibrium, Gujarati and Porter (2010) indicate that the error correction term (ECT) must be negative and statistically significant. The error correction term of -0.2264 indicates that 22.51 percent of disequilibrium between the variables will be corrected each year. Therefore, it will take one year to restore long-run equilibrium in GDP when government debt, foreign debt, investment and government expenditure changes are considered. The results further indicate that economic growth is positively stimulated by government debt, foreign debt and investments in the short run. The results highlight the fact that external debt is not always harmful to a nation's economy; however, having a large amount of external debt does not only imply that growth will be low but further asserts the dangers associated with the inability to pay back the loan money as seen in many African countries (Were, 2001).

\subsubsection{Causality test}

The presence of the co-integrating relationship suggests that there should at least be one causal relationship between economic growth, foreign debt, domestic debt, investment and government expenditure. Because the variables were integrated at $\mathrm{I}(0)$ and $\mathrm{I}(1)$ jointly, the T-Y Granger causality test was utilised. Using the information criteria, 1 lag was selected. The results are presented in Table 5 below.

Table 5: Causality results

\begin{tabular}{|l|l|l|l|l|l|l|l|}
\hline Dependent variable: LGDP & \multicolumn{3}{l|}{ Dependent variable: LEXP } \\
\hline Excluded & Chi-sq & df & Prob & Excluded & Chi-sq & df & Prob \\
\hline LEXP & 2.3048 & 2 & 0.3159 & LGDP & 0.9366 & 2 & 0.6261 \\
\hline LGD & 7.4043 & 2 & $0.0247^{*}$ & LGD & 4.3806 & 2 & 0.1119 \\
\hline LFD & 16.8942 & 2 & $0.0002^{*}$ & LFD & 3.0712 & 2 & 0.2153 \\
\hline LINV & 10.9072 & 2 & $0.0043^{*}$ & LINV & 0.3351 & 2 & 0.8457 \\
\hline All & 25.0472 & 8 & 0.0015 & All & 19.9086 & 8 & 0.0107 \\
\hline
\end{tabular}




\begin{tabular}{|l|l|l|l|l|l|l|l|}
\hline Excluded & Chi-sq & df & Prob & Excluded & Chi-sq & df & Prob \\
\hline LGDP & 16.3491 & 2 & $0.0003^{*}$ & LGDP & 0.3755 & 2 & 0.8288 \\
\hline LEXP & 4.9646 & 2 & $0.0006^{*}$ & LEXP & 1.3268 & 2 & 0.5151 \\
\hline LFD & 0.3531 & 2 & 0.8382 & LGD & 3.1360 & 2 & 0.2085 \\
\hline LINV & 1.2838 & 2 & 0.5263 & LINV & 1.7001 & 2 & 0.4274 \\
\hline All & 36.5662 & 8 & 0.0000 & All & 11.6830 & 8 & 0.1659 \\
\hline Dependent variable: LINV & Chi-sq & df & Prob & & & & \\
\hline Excluded & Chi & & & & \\
\hline LGDP & 5.8774 & 2 & $0.0529^{*}$ & & & & \\
\hline LEXP & 0.1750 & 2 & 0.9162 & & & & \\
\hline LDG & 0.6934 & 2 & 0.7070 & & & & \\
\hline LFD & 2.8604 & 2 & 0.2393 & & & & \\
\hline All & 22.3789 & 8 & 0.0043 & & & & \\
\hline Note: ${ }^{*}$ denotes $5 \%$ level of significance & & & & \\
\hline
\end{tabular}

Source: Own table based on results obtained from Eviews 9

The results from the study indicate that there is a unidirectional causality between LFD and economic growth, followed by a unidirectional causality between LEXP and LGD. The results further reveal a bidirectional causality between LGD and LGDP. This implies that changes in government debt will granger case changes in economic growth and vice versa. The results support the idea that large amounts of debt serve as an obstruction to the country's economic and financial development (Mutasa,2003; Audu, 2004). As in the case where the isn't sufficient growth in a country, and as a means of supporting public and profitable investment such as investment in human resource, physical infrastructure and spending on healthcare and education, government may accumulate public debt (Belguith and Omrane,; 2017).Furthermore, a bidirectional causality between LINV and LGD is observed. This indicate that changes in investments will granger cause changes in government debt and vice versa. This implies that if South Africa generates enough investments, then the government will have enough capital resources to fulfil its duties and not borrowing. Likewise having an unsustainable high amount of debt will serve as an indicator that will discourage investors form investing in South Africa.

\subsection{DIAGNOSTICS AND STABILITY TEST}

In order to check the robustness of the model, various diagnostics and stability tests were employed. The results of the diagnostics and stability tests are presented in Table 6 below.

Table 6: Diagnostics test results

\begin{tabular}{|l|l|l|l|}
\hline Test & Hypothesis & Probability & Conclusion \\
\hline Breusch-Godfrey & No serial correlation & 0.2852 & No serial correlation \\
\hline White & $\begin{array}{l}\text { No } \\
\text { heteroscedasticity }\end{array}$ & 0.7517 & $\begin{array}{l}\text { No } \\
\text { heteroscedasticity }\end{array}$ \\
\hline Jarque-Bera & $\begin{array}{l}\text { Residuals are } \\
\text { normally distributed }\end{array}$ & 0.5457 & $\begin{array}{l}\text { Residuals are } \\
\text { normally distributed }\end{array}$ \\
\hline $\begin{array}{l}\text { CUSUM and } \\
\text { CUSUMSQ }\end{array}$ & $\begin{array}{l}\text { Model remains within the critical boundaries } \\
\text { (upper and lower) }\end{array}$ & $\begin{array}{l}\text { Model is stable at } \\
5 \% \text { level of } \\
\text { significance }\end{array}$ \\
\hline
\end{tabular}

Source: Own table based on results obtained from Eviews 9

Taking into account the $5 \%$ level of significance, the results of this study show that all probability values are significant. This accordingly infers that the null hypothesis cannot be rejected. The 
outcomes acquired by the study further demonstrate that the model used met all the vital econometric assumptions, as there is no autocorrelation, no heteroscedasticity, and the residuals are normally distributed. As a means of ensuring stability, the CUSUM and CUSUMQ tests were conducted, where the results confirm that plot recursive residuals indicated by the line within the $5 \%$ parameter lie within the confidence band, thereby indicating that the model used in this analysis is stable.

\subsection{CONCLUSION AND RECOMMENDATIONS}

The study's main objective was to analysis the relationship between government debt, foreign debt and economic growth in South Africa. The results obtained from the study indicate that there is a positive relationship between foreign debt, investment and economic growth, while a negative relationship was observed between government debt, expenditure and growth. The results of this study reveal that South Africa's spending exceeds its revenue, where the consolidated government expenditure for 2018/2019 was recorded at R1.67 trillion, and the budget revenue for 2018/2019 was recorded at just over R1.49 billion (Budget Review, 2018). This has contributed to the increasing foreign debt levels that ultimately negatively affect economic growth in South Africa.

Based on the findings and taking into account the literature provided, the South African government should therefore find measures and improve existing debt management policies that will increase efficiency in terms of how and where revenue is spent. This, in turn, could fight corruption and the misuse of funds and ensure that money is injected into the right industries and departments. In addition, the South African government should also focus on achieving inclusive growth, by investing more into the agricultural sector, as the agricultural sector is the largest contributor to South Africa's GDP. In this way, it will enable South Africa to export more goods, which will help alleviate the deficit problem and create revenue for the country, which will therefore reduce borrowing. Furthermore, the South African government should also consider reducing the size of the cabinet and national government department, as this will save the government R122 million in 2018/2019, as indicated by Business Tech (2018). This could be contributing to South Africa's debt problem. Moreover, the South African government should consider either partially or fully privatising state-owned companies as they are becoming a liability, since the revenue used by the government to bail out these entities could have been allocated to other capital forming activities and also on paying off debt service costs. In conclusion, the government should encourage foreign direct investment as a productive investment, which will enable them to limit the subjectivity of obtaining borrowed funds so as to fund infrastructure and other development projects in South Africa. In this way, South Africa ought to secure external loans for well-evaluated, self-liquidating and high priority projects that will lead to positive change in the economy. 


\section{References}

Abu-Bader, S. \& Abu-Qarn, A.S. 2003. Government expenditures, military spending and economic growth: Causality evidence from Egypt, Israel, and Syria, Journal of Policy Modelling, (25):567-583.

Ahmed, Y., Saeed, S.T. \& Saed, S.J.H. 2015. The impact of external debt on economic growth: Emphirical evidence from Iraq. International Journal of Science and Research, 4(8):2319-7064 Audu, S.I. 2004. the impact of external debt on economic growth and public investment. The case of Nigeria. African Institute for Economic Development and Planning (IDEP) Dakar Segegal. http://www.unidep.org. Date of access: 12 March 2016.

Ayadi, F.S. \& Ayadi, F.O. 2008. The impact of external debt on economic growth: A comparative study of Nigeria and South Africa, Journal of Sustainable Development in Africa, 10(3):2342Saharan Africa. Economic Issue is based on IMF Working Paper 99/51.

Belguith, S.O. \& Omare, H. 2017. Macroeconomic determinants of public debt growth: A case for Tunisia. Journal of Applied Economics, 4(613):161-168.

Budget Review. 2018. National Treasury Republic of South Africa. file://C:/Users/23722657/Desktop/ARDL\%20DEBT/2018\%20BUDGET\%20REVIEW.pdf. Date of access: 3 March 2018

Brinded, L. 2016. The 19 countries with the highest levels of government debt. Business insider, Friday 30 September 17:33. https://www.independent.co.uk/news/business/the-19-countries-withthe-highest-level-of-government-debt-a7340121.html. Date of access: 08 June 2019.

BusinessTech. 2018. https://businesstech.co.za/news/finance/226685/14-ways-government-canfree-up-over-r110-billion-in-the-budget/. Date accessed: 24 August 2018.

Chiu, Y.B. \& Lee, C.C.(2017. The impact of public debt on economic growth: Does country risk matter? Contemporary Economic Policy, 35(4):751-766.

Cooray, A., Dzhumashev, R. \& Scneider, F. 2016. How does corruption affect public debt? An empirical analysis, World Development, 2016

Da Veiga, L., Ferrerira, L.J., Tiago, A. \& Tiago, S. 2014. Public debt, economic growth, and inflation in African economies. Munich Personal RePEc Archive Paper no.57377. https://mpra.ub.uni-muenchen.de/57377/. Date of access: 17 August 2016. 
Diallo, B. 2009. External debt and financing of economic development in Guinea. National Directorate of Economic Studies and Forecasting, Ministry of Economy and Finance, ConakryRepublic of Guinea.

Drazen, A. 2000. Political economy in macroeconomics, Princeton: Princeton University Press. Edwards, Sebastian and Guido, Tabellini, 1991. Explaining Fiscal Policies and Inflation in Developing Countries, Journal of International Money and Finance, 10(1):16-48.

Dumitrescu, B.A. 2014. The public debt in Romania factors of influence, scenarios for the future and a sustainability analysis considering both a finite and infinite time horizon, Procedia Economics and Finance, 8(2014):283-292.

Easterly, W. 2002. How did heavily indebted poor countries become so heavily indebted? Reviewing two decades of debt relief.

https://williameasterly.files.wordpress.com/2010/08/35_easterly_howdidheavilyindebtedpoorcountriesbeco meheavilyindebted_prp.pdf. Date of access: 25 April 2017.

Geiger, L.T. 1990. Debt and economic development in Latin America. The Journal of Developing Areas, 24:181-194.

Gohar, M., Bhutto, N.A. \& Butt, F. 2012. The impact of external debt servicing on the growth of low income countries, Sukkur Institute of Business Administrations, Proceedings of $2^{\text {nd }}$ Conference on Business Management. (ISBN: 978-969-9368-06-6).

Habanabakize, T. \& Muzindutsi, P.F. 2017. Analysis of government expenditure and sectorial employment in the post-apartheid South Africa: Application of ADRL Model. Journal of Economic and Behavioral Studies, 9(2):224-233.

Hassan, S.U. \& Mamman, A. 2013. External debt and economic growth: Evidence from Nigeria. International Journal of Economics, Business and Finance, 1(10):360-370.

Holtfrerich, C., Feld, L.P., Heun, W. et al. 2016. Government debt: Causes, effects and limits. Berlin, pp.76 https://www.akademienunion.de/fileadmin/redaktion/user upload/Publikationen/Stellungnahmen/3Akad Be richt Staatsschulden2015 EN web.pdf. Date of access: 08 May 2016 Imbeau, L.M. \& Pe'try, F. 2004. Politics, institutions, and fiscal policy: Deficits and surpluses in Federated States. Lanham, MD: Lexington Books.

Kumar, M.S. \& Woo, J. 2010. Public debt and growth. IMF Working Paper 174. Washington DC: IMF. Kwoba, P.L. \& Kosimbei, G. 2015. Public debt and economic growth in East African community, Economic and Finance Review, 4(5):31-39. 
Mah, G., Mukkudem-Peterson, J. \& Miruka, M.A. 2013. The impact of government expenditure on the Greek government debt: An econometric analysis. Mediterranean Journal of Social Science, 4(3):20392117.

Mahmoud, L.O.M. 2015. The role of external debt on economic growth: Evidence from Mauritania. International Journal of Economics and Management Sciences.

Malik, S., Hayat, M.K. \& Hayat, M.U. 2010. External debt and economic growth: Empirical evidence from Pakistan. International Research Journal of Finance and Economics, ISSN 1450-2887, 44:88-97

Ncanywa, T. \& Makhenyane, L. 2016. Can investment activities in the form of capital formation influence economic growth in South Africa? In M.P. Sebola \& J.P. Tsheola (eds.). SAAPAM Limpopo Chapter $5^{\text {th }}$ Annual Conference Proceedings 2016 (pp.270-279). Hatfield: SAAPM Limpopo Charter.

Miller, S.M. \& Russek, F.S. 1997. Fiscal structures and economic growth: International evidence. Economic Inquiry, (35):603-613.

Moki, M. 2012. The relationship between public debt and economic growth in Africa. Unpublished MBA Project, University of Nairobi.

Muhdi \& Sasaki, K. 2009. Roles of external and domestic debt in economy: Analysis of a macroeconometric model for Indonesia. Interdisciplinary Information Sciences, 15:251-265.

Mutasa, C. 2003. Regional integration and debt in Africa: A comprehensive report of Africa's regional groupings. AFRODAD Research series. March.

Leao, P. 2013. The effect of government spending on the debt-to-GDP ratio: Some Keynesian arithmetic, Metroeconomica, 64(3):448-465.

Pesaran, M.H., Shin, Y. \& Smith, R.J. 2001. Bounds testing approaches to the analysis of level relationships. Journal of Applied Econometrics, 16(3):289-326.

Reinhart, C.M. \& Rogoff, K.S. 2010a. Growth in a time of debt. American Economic Review, 100(2):573578.

Sinha, P., Arora, V. \& Bansal, V. 2011. Determinants of public debt for middle income and high income group countries using panel data regression, Munich Personal Repec Archive (MPRA Paper, No. 32079). StatsSA. 2018. The economy shrinks by $0.7 \%$ in Q2:2018. http://www.statssa.gov.za/?p=11507. Date of access: 22 May 2019.

Sulaiman, L.A. \& Azeez, B.A. 2012. Effects of external debt on economic growth of Nigeria. Journal of Economics and Sustainable Development, 3:71-79.

Swamy, V. 2015. Government debt and its macroeconomic determinants: An empirical investigation, Munich Personal Repec Archive (MPRA Paper, No. 64106). 
Varughese, R. 1999. Government finance: Public debt of Kerala 1974-75 to 1996-97. (Unpublished PhD Thesis). Cochin University of Science and Technology, Nairobi. Kenya, Economic and Finance Review, $4(5): 31-39$.

Were, M. 2001. The impact of external debt on economic growth in Kenya. World Institute for Economics Research. Working paper 2001/116. United Nations University.

World Bank. 2016. World Development Indicators. http://data.worldbank.org/data-catalog/worlddevelopment-indicators. Date of access: 12 July 2016.

Word Debt Clock. https://commodity.com/debt-clock/. Date of access: 08 June 2019. 